\title{
Könyvszemle
}

SIPOS JÚLIA GONDOZÁSÁBAN

\section{A „FÖLD VÉSZJELEI", AVAGY A KLÍMAVÁLTOZÁS SZOCIOLÓGUS SZEMMEL}

Az éghajlatváltozás témájában ugyan sokáig éles tudományos és politikai viták zajlottak, mára azonban a légköri jelenségeket vizsgáló mértékadó tudományos testületek megállapították, hogy az éghajlatváltozást előidéző tényezők egy része emberi tevékenységböl adódik - mutat rá Antal Z. László új könyvében (15.). A természeti erőforrásokat egyre nagyobb mértékben felélő ipari tevékenység súlyos krízist idézett elő. Az Éghajlatváltozás és szociológia címü kötet a válságjelenségek közül az éghajlatváltozást helyezi a középpontba. A társadalmak egyre inkább szembesülnek ugyanis a fokozódó felmelegedés hatásaival, a légkör szélsőséges jelenségeivel, a tomboló erejü viharok, áradások növekvő gyakoriságával.

Közel fél évszázada a Római Klub tudósai hívták fel a veszélyekre elsőként a figyelmet. Jelentésükben, 1972-ben számításaik alapján rámutattak, hogy az exponenciális gazdasági növekedés és a Föld lakosságának gyarapodása nem tartható fenn, mert az emberiség tartalékai és az élőhelyek belátható időn belül elfogynak. Az erőforrások végzetes elapadása mellett a légszennyezés, az ózonréteg korábbi megkárosítása, a természetes élőhelyek, valamint a vizek és vizes élőhelyek szennyezésének következményeképpen felgyorsult a biodiverzitás csökkenése, vagyis az élőhelyek pusztulása miatt egyre több faj pusztul ki. Az emberi szervezet is egyre több káros hatásnak lesz kitéve a szennyezés és a klímaváltozás következményei miatt. „Ha az iparilag fejlett országok vezetői és az ezekben az országokban élő emberek jelentős része is jól tudja, hogy az ökológiai válság és az éghajlatváltozás milyen kockázatokat jelent számukra, akkor milyen társadalmi, gazdasági és politikai feltételek akadályozzák meg, hogy megtegyék azokat a lépéseket, amelyeket ők maguk a társadalom stabilitása és fennmaradása érdekében szükségesnek tartanak?" - teszi fel a programadó kérdést a klímakutatás társadalmi aspektusainak vizsgálatához Antal Z. László.

Azzal, hogy most már a meghatározó nemzetközi tudományos testületek is az éghajlatváltozást előidéző tényezők közé sorolják az emberi tevékenységet, 
magától értetődővé válik a társadalmi tényezők vizsgálata is a klímakutatásban a korábban meghatározóan természettudományos megközelítések mellett. Eddig ugyanis „az éghajlatváltozást elválasztották társadalmi kontextusától” - idézi a szerző Mike Hulme professzort (17.). A társadalmi tényezők vizsgálata érdekében az Amerikai Szociológia Társaság keretei között 2010-ben létrehoztak egy testületet, és kutatásaik összefoglalásaképpen 2015-ben jelentették meg a Climate Change and Society, Sociological Perspectives címü könyvet, amely az éghajlatváltozás szociológiai vizsgálatában fontos modell volt Antal Z. László számára.

2019-ben napvilágot látott - korábban megjelent munkáinak gyüjteményét tartalmazó - kötete több szempontból is különlegességnek számít a hazai szociológiai irodalmon belül. A szakma ugyanis most kezdi a klímaváltozás társadalomtudományi kutatásának jelentőségét elismerni (az elmúlt évtizedekben bizony ez a terület peremhelyzetben volt a szociológiai berkekben). Ezúttal a szakma rangos kitüntetéssel díjazta Az éghajlatváltozás és szociológia címü tanulmánykötet szerzőjeként Antal Z. Lászlót, hiszen kötetét a Magyar Szociológiai Társaság legutóbbi éves közgyülésén Polányi-díjjal tüntette ki a legjobbnak ítélt hazai szociológiai könyv kategóriában.

A kötet programadó mivolta miatt is különös figyelmet érdemel. A szerző ugyanis e közel húsz év munkáit összefoglaló müvében a szociológia új szerepét keresi az emberiség egészét érintő, az életfeltételeinket meghatározó éghajlatváltozás jelenségének társadalmi vonatkozásainak feltárásában, hogy megalkothassa az új feltételekhez való adaptáció, továbbá a fenntarthatóság társadalmi modelljeit. Körbejárja, milyen feloldása lehet a klímaparadoxonnak, vagyis annak, hogy az éghajlatváltozás káros hatásainak tudatában sem történik jelentős áttörés a társadalomszervező elvekben, az életformákban, gazdasági szerkezetekben.

Antal Z. László új kötetével támogatni kívánja azt a törekvést, amely „azért folyik, hogy Magyarországon a tudományos kutatók, a felsőoktatásban dolgozó oktatók, a kormány, az önkormányzatok, a sajtó munkatársai, a társadalom különböző csoportjai és lehetőleg minden ember megismerje az éghajlatváltozás kockázatait, ezek csökkentési lehetőségeit, és azt is, hogyan lehet felkészülni a várható változásokra" (8.) - ahogy ezt a kötet Bevezetőjében megfogalmazza.

A szerző a kétezres évek elejétől foglalkozik közelebbről a környezet és a társadalom kapcsolatával, és számos kezdeményezést indított. Ezek korábbi, egészségszociológiai munkáinak szellemiségéhez is kapcsolódnak. 2005-ben Éghajlatváltozás Kutatómühelyt szervezett az MTA Szociológiai Kutatóintézetében, és a Magyar Szociológiai Társaságban nem sokkal ezután megalapította a Holisztikus ökológia szakosztályt. Részt vett az MTA és a Környezetvédelmi Minisztérium együttmüködésében megvalósult VAHAVA (Változás-HatásVálaszadás) kutatási programban (2003-2006), amely a globális klímaváltozás 
hazai hatásait vizsgálta. Alapítója volt a Klímabarát Települések Szövetségének. A csatlakozó önkormányzatokkal helyi szintű éghajlatváltozási stratégiákat dolgoztak ki. Az ehhez kapcsolódó kutatás keretében pedig vizsgálta a természeti változásokhoz való alkalmazkodást segítő és akadályozó társadalmi, gazdasági és politikai feltételeket. Eredményeit a Klímabarát települések címü kötetében adta közre 2008-ban. Az UV-sugárzással foglalkozó vezető hazai intézményeinek részvételével 2009-ben egyik megalakítója volt a Napsugárzásvédelmi Tudományos Testületnek. Részt vett tematikus konferenciák szervezésében, amelyek az egészség és éghajlatváltozás, a természet és társadalom kapcsolatát, valamint a Napnak az emberi kultúrákban betöltött szerepét tárgyalták. Az Éghajlatváltozás és szociológia címü kötet összefoglalja tehát mindezen törekvések és kutatások eredményeit, már megjelent tanulmányokat és konferenciabeszámolókat is tartalmazva. A szövegeket egymás után olvasva így sok visszautalást, ismétlést találunk, korábbi eredményeinek áttekintése kapcsán.

A kötet egyben roppant izgalmas vállalkozás. Antal Z. László a szociológia diszciplináris kereteit feszegeti. A holisztikus szemlélet bevonásával nemcsak arra tesz kísérletet, hogy a természet és társadalom szempontjait egyaránt érvényesítse az éghajlatkutatás kapcsán, hanem referenciakeretét a társadalomtudománynál szélesebbre nyitja, így például kultúrtörténeti szempontokat, irodalmi vagy vallási szövegeket is ötvöz témájának kifejtésében. Hangsúlyozza továbbá társadalmi alternatívák jelentőségét, beszámol ökológiai mozgalmakról és önellátó, biogazdálkodást folytató életmódkísérletekről. A társadalom egy része már felfigyel az ökológiai válság és a klímaváltozás jelenségeire, és egyre inkább tisztában van a kockázatokkal, ahogy ezt Ferencz Zoltánnal együtt végzett kutatása alapján megállapítja.

A szerző kitér Al Gore 2006-ban készült, Kellemetlen igazság (The Inconvenient Truth) címü filmjére, amellyel kapcsolatban elhangzott, hogy a klímaváltozás mára már nem politikai, hanem morális kérdéssé vált. Hasonló szellemü filmeket forgattak azóta is: például az amerikai színész, Leonardo di Caprio Az Özönvíz elött (Before the Flood), valamint az életét természetfilmek forgatásának szentelő, és munkásságának elismeréseképpen 1985-ben lovaggá ütött brit természettudós, Sir David Attenborough 93 évesen 2020-ban készített, Egy élet a bolygónkon (Life on Our Planet) címü filmje. Ennek megrendítő, bevezető sorait idézhetjük itt, megerősítve a morális felelősség szempontjának fontosságát: „Az élővilág egy egyedülálló, látványos csoda. Ám az emberek életvitelének köszönhetően hanyatlásnak indult."

Egyre többen figyelnek föl tehát arra, hogy Földünk „vészjelzéseket” ad le. A cselekvés és szemléletváltozás szükségszerüségére, az emberi létformák és társadalmi berendezkedések egyes elemei megváltoztatásának jelentőségére hívja fel a figyelmet a társadalomtudós is. Antal Z. László kötete azt sugallja, hogy a 
vészjelek észlelésén és dekódolásán túl közös felelősségünk az adaptáció módjainak megtalálása és a krízis tovább mélyülésének megakadályozása. Mindebben a szerző szerint az elhivatott szociológusnak és a társadalomtudományoknak fontos szerepe lehet.

(Antal Z. László: Éghajlatváltozás és szociológia. Budapest: Társadalomtudományi Kutatóközpont-Argumentum Kiadó, 2019, 197 o.)

Acsády Judit

PhD, szociológus a Társadalomtudományi Kutatóközpont Szociológiai Intézetének tudományos főmunkatársa 